\title{
REBOUND PHENOMENON - IMPORTANT AND UBIQUITOUS IN PHARMACOTHERAPY
}

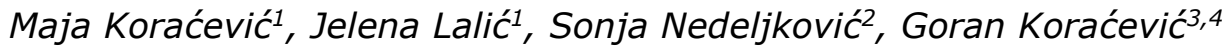

\begin{abstract}
The rebound effect represents a common characteristic of the numerous classes of modern drugs and can result in serious and even fatal disorders. For example, prolonged administration of proton pump inhibitor (PPI) leads to moderate hypergastrinemia in $20-25 \%$. This hypergastrinemia will result in rebound gastric acid hypersecretion in $30-40 \%$ of patients following the abrupt PPI discontinuation. PPIs are among the most widely used drugs worldwide.

An abrupt cessation of chronic corticosteroid, beta blocker, or opioid treatment may also provoke rebound phenomenon. Even in heart failure patients, beta blocker withdrawal on admission resulted in a significant increase of the probability of in-hospital mortality. The incidence of a rebound phenomenon depends on numerous factors, including the intensity and duration of action of a particular drug and how long it has been applied; the susceptibility of an individual patient (regarding the comorbidities and the severity of the primary disease) and the related circumstances (e.g, co-therapy). The clinical importance of the rebound phenomenon varies from academic to lethal. Even rare rebounds found for some classes of drugs are becoming very important if the drug has been used often globally.
\end{abstract}

Acta Medica Medianae 2018;57(4):148-152.

Key words: rebound, proton pump inhibitor, corticosteroid, beta blocker, opioid

\author{
${ }^{1}$ University of Niš, Faculty of Medicine, Department of \\ Pharmacy, Niš, Serbia \\ ${ }^{2}$ Pharmacy "Nevenpharm", Niš, Serbia \\ "University of Niš, Faculty of Medicine, Niš, Serbia \\ ${ }^{4}$ Department for Cardiovascular Diseases, Clinical Center Niš, \\ Serbia
}

Contact: Maja Koraćević

Adress: 9. brigade 53/50, 18000 Niš, Serbia

E-mail: koracevic.maja@gmail.com

\section{Introduction}

Rebound phenomenon is defined as a worsening of symptoms even exceeding baseline levels when the drug is abruptly discontinued or loses effectiveness $(1,2)$. The rebound effect represents a common characteristic of the numerous classes of modern drugs. It is difficult to find a part of pharmacotherapy without a good example of rebound phenomenon following sudden drug withdrawal. In order to preserve homeostasis, several pathophysiological mechanisms become activated following the introduction of a drug. For example, if a drug blocks a process for enough long period of time, the number of receptors on target cells will increase (up-regulation), aiming to overcome the blockade. Therefore, sudden withdrawal of an efficacious medicament will allow the stimulant to act on increased number of receptors on target cells, resulting in the rebound of symptoms and signs of the disease. This explains (in a simplified way) how can symptoms and signs not only return following the drug cessation, but become even worse compared to pre-treatment period. Depending upon the drug efficacy and eventual important co-therapy on the one hand and severity of the disease (among other factors) on the other hand, the rebound effect can result in serious and even fatal disorders (1).

The aim of the study is to give a short review of the various examples of rebound phenomenon and to illustrate how ubiquitous and important in pharmacotherapy it is.

\section{Literature overview}

A typical example of rebound phenomenon occurs following a sudden proton pump inhibitors (PPIs) discontinuation. With commencing PPI, in order to preserve homeostasis and to overcome the gastric acid secretion blockade, numerous pathophysiological mechanisms change, including the stimulation of gastrin secretion, which becomes moderate in $20-25 \%$ of chronic PPI users $(1,3,4)$. Namely, as a result of prolonged PPI administration, gastric hypoacidity ensues, resulting in the inhibition of the feedback mechanism initiated by antral mucosal acid sensors. Therefore, antral G-cell release of gastrin is 
not suppressed, which leads to chronic hypergastrinemia, gastric parietal, and ECL-cell hyperplasia (4, 5). Among other consequences, hypergastrinemia will result in rebound gastric acid hypersecretion in $30-40 \%$ of patients following the abrupt PPI termination $(1,5)$. Due to cell hyperplasia (which is not a short-time abnormality), rebound gastric acid oversecretion may last for weeks. There is no consensus how long this hypersecretion averages, but some estimates suggest 6-8 weeks, but $<26$ weeks.

This becomes even more important if we have in mind that PPIs are among the most widely used drugs worldwide, approximating US $\$ 13$ billion in sales per year. Long-term usage of PPIs is not approved, but they became over-the-counter drugs in the USA, leading to the lack of efficient control in the PPI administration (5). Therefore, sudden PPI withdrawal occurs more often. Moreover, some authors estimate that $25-81 \%$ of PPI users lack valid indication. Additionally, among patients with adequate diagnosis requiring PPI (e.g, Helicobacter pylori eradication), many continue PPI utilization despite the reason for it has disappeared meanwhile (6). Pharmacists should help to decrease the inappropriate medication use. One cross-sectional study recommended patients education about the proper drug cessation (e.g. PPI), particularly because the dose tapering is required to diminish the risk of rebound syndrome (6). It has been suggested that PPI dose should be diminished before cessation. After the sudden PPI cease, rebound hyperacidity can occur resulting in the worsening of symptoms; this can be easily misinterpreted as the disease relapse, leading to new whole -length course of PPI treatment, which is clearly unnecessary (6). A proper way to quit PPI therapy seems to be halving the PPI dose for a month or two and then ceasing PPI or to switching to a less effective acid suppressant (H2 blocker). Indeed, an antacid should be prescribed to control dyspepsia (6).

2. As for psoriasis, there is a clear definition of rebound: it is present with either a flare-up > 125\% of baseline Psoriasis Area and Severity Index or with a morphological difference (for example, erythrodermic or generalized pustular psoriasis) (7). Sudden withdrawal of a strong, efficient drug without tapering might result in rebound of psoriasis $(7,8)$. The incidence rebound phenomenon of drug should be reported, such as in a study of etanercept (9).

3. It is well known that an abrupt cessation of chronic corticosteroid treatment may provoke rebound syndrome (10). Rebound syndrome following sudden cessation of corticosteroids is very important, particularly if intravenous route of administrative is used. A recent consensus document on the appropriate use of inhaled corticosteroids in chronic obstructive pulmonary disease has also recommended that the dose of inhaled corticosteroids should be tapered before stopping (10-12).

A step-wise withdrawal of inhaled corticosteroids is recommended based in part on the results of the WISDOM (Withdrawal of Inhaled Steroids During Optimized Bronchodilator Management) trial (2,027 patients finished the trial). The daily dose of an inhaled corticosteroid should be gradually diminished by approximately $50 \%$ at randomization and again at 1,5 month; after a three-month treatment with inhaled corticosteroids, the therapy should be completely ceased $(10,12)$. For the whole period patients should receive tiotropium $18 \mathrm{mg}$ QD and salmeterol $50 \mathrm{mg}$ BID (12). Shortly after withdrawal, patients who have ceased to inhale corticosteroids should be seen again (as outpatients). It is safe to stop inhaled corticosteroids even in severe chronic obstructive pulmonary disease patients. In order to proceed with step-wise dose reduction, it is important to document the absence of decline in FEV1 after decreasing the dose of inhaled corticosteroid from high to medium one (11).

4. Due to high analgesic efficacy, opioid (e.g, morphine) is frequently the drug of choice for the treatment of severe pain. The number of young individuals addicted to opioids has been increasing during the past decade as well as opioid withdrawal syndrome (recognized by respiratory depression, cramps, changes in body temperature, diarrhea and vomiting, tachycardia, arterial hypertension, etc.) (13). Following a prolonged use of opioids, tolerance may occur decreasing their efficacy and patient requires higher doses to maintain pain control (14). This dose escalation parallels a higher incidence of unwanted effects and eventual withdrawal syndrome may become more severe, too. In one study, all 35 patients had opioid rebound syndrome, which indicated physical dependence (14). Endothelin-A receptor antagonists may diminish the dose of opioids and some of their adverse effects such as respiratory depression (13). Rebound syndrome following the abrupt discontinuation of opioid infusion after $\geq 5$ days is found in $>30 \%$ in pediatric intensive care unit patients (15).

5. Rebound syndromes have been reported after a sudden withdrawal of various drugs used in cardiology, starting from heparin rebound and beta blocker (BB) rebound (14, 17-25).

If there is no contraindication (such as allergy), it seems wise to use a selective and/or vasodilatatory $\mathrm{BB}$. The reason for such recommendation is in the fact that selective BBs have less common unwanted effects and consequently higher compliance, adherence and persistence. Therefore, it is logical to expect fewer withdrawals and possible rebound phenomena (17). Moreover, chances to forget to take a drug are higher if it is prescribed e.g., three times daily (in comparison with once-daily. Thus, long-lasting drugs (including BBs) have lower probability of dose omitting and can be recommended. It is also rational to pay attention to the price of particular BB, because if it is currently or prospectively too high for a given patient, it might favor patient's decision to stop taking it. Indeed, patients will be more complaint to the prescribed BB regimen if they are informed about the risk associated with sudden BB withdrawal. It is particularly important for patients on high BB daily dose as the chances for rebound rise in parallel with the dose (17). Common sense also suggests that proper BB should be administered, which is evidence-based and recommended in contemporary guidelines for this patient's indication. For example, some BBs are recommended for heart failure, while others are not. Prescribing one of adequate BBs for this particular indication 
leads rationally to the expectation of an improvement in symptoms (which will enhance the persistence and diminish the dose omission and resultant $\mathrm{BB}$ rebound). Moreover, patients should be instructed to take BB as soon as possible in the morning in order to cope with early morning sympathetic activation and subsequent morbidity and mortality risk. Namely, the risk of major adverse cardiac and cerebral events is several-fold higher in the first hour(s) after awaking and it is not rational to raise this risk even more with $\mathrm{BB}$ rebound.

BB rebound has been well-known. Patients might even misuse this knowledge to induce facticious hypertension (16). Yet, in heart failure patients with BB withdrawal at admission to hospital, the OR was 1.77 (1.09-3.26) for in-hospital mortality in the BETAWIN-AHF study. It is consonant previous studies including a recent meta-analysis: a risk ratio of 1.59 (1.03-2.45) for death or rehospitalization (18).

In numerous patients with arrhythmic events, despite therapy, non-compliance may be responsible with the resulting BB rebound phenomenon (22). Moreover, in order to avoid BB rebound, BB should not be stopped in the perioperative period. The dose of $\mathrm{BB}$ should be adjusted to achieve the heart rate 60-70 beats per min, and systolic blood pressure should be $>100 \mathrm{mmHg}$ (26). Recommendation that the dose of propranolol should be carefully tapered before its discontinuation (together with diminished physical activity) has been adequate for four decades (24).

\section{Conclusions}

1. Rebound symptoms and signs following the abrupt discontinuation of the drug use have been registered in numerous (almost all) areas of medicine.

2. The incidence of a rebound phenomenon depends on numerous factors, including the intensity and duration of action of a particular drug and how long it has been applied; the susceptibility of an individual patient (regarding the comorbidities and the severity of the primary disease) and the related circumstances (e.g, co-therapy).

3. The clinical importance of the rebound phenomenon varies from academic to lethal, depending on the drug and clinical scenario.

4. Even rare rebounds found for some classes of drugs are becoming very important if the drug has been often used globally.

\section{References}

1. Teixeira MZ. Rebound effects of modern drugs: serious adverse events unknown by health professionals. Rev Assoc Med Bras 2013; 59(6):629-38. [CrossRef] [PubMed]

2. Ooms $P$, Blankers $M$, Figee $M$, Mantione $M$, van den Munckhof $P$, Schuurman PR, et al. Rebound of affecttive symptoms following acute cessation of deep brain stimulation in obsessive-compulsive disorder. Brain Stimul 2014; 7(5):727-31. [CrossRef] [PubMed]

3. Waldum HL, Hauso $\varnothing$, Brenna $E$, Qvigstad G, Fossmark R. Does long-term profound inhibition of gastric acid secretion increase the risk of ECL cell-derived tumors in man? Scand J Gastroentero 2016; 51(7): 767-73. [CrossRef] [PubMed]

4. Nandy N, Hanson JA, Strickland RG, McCarthy DM. Solitary gastric carcinoid tumor associated with longterm use of omeprazole: A case report and review of the literature. Digest Dis Sci 2016; 61(3):708-12. [CrossRef] [PubMed]
5. Sukhovershin RA, Cooke JP. How may proton pump inhibitors impair cardiovascular health? Am J Cardiovasc Drugs 2016; 16(3):153-61. [CrossRef] [PubMed]

6. Pasina L, Urru SA, Mandelli S, Giua C, Minghetti P. Evidence-based and unlicensed indications for proton pump inhibitors and patients' preferences for discontinuation: a pilot study in a sample of Italian community pharmacies. J Clin Pharm Ther 2016; 41(2):2203. [CrossRef] [PubMed]

7. Daudén $E$, Puig $L$, Ferrándiz $C$, Sánchez-Carazo JL, Hernanz-Hermosa JM. Consensus document on the evaluation and treatment of moderate-to-severe psoriasis: Psoriasis Group of the Spanish Academy of Dermatology and Venereology. J Eur Acad Dermatol 2016; 30(Suppl 2):1-18. [CrossRef] [PubMed]

8. Khemis A, Cavalié M, Montaudié $H$, Lacour JP, Passeron $\mathrm{T}$. Rebound pustular psoriasis after brodalumab discontinuation. Brit J Dermatol 2016; 175(5):1065-6. [CrossRef] [PubMed] 
9. Prinz JC, Puig L, Girolomoni G. Treatment of psoriasis with etanercept: the typical patient profile. J Eur Acad Dermatol 2016; 30(7):1092-9. [CrossRef] [PubMed]

10. Kaplan AG. Applying the wisdom of stepping down inhaled corticosteroids in patients with COPD: a proposed algorithm for clinical practice. Int J Chronic Obstr 2015; 10(1):2535-48. [CrossRef] [PubMed]

11. Alcázar Navarrete B, Casanova C, Miravitlles M, de Lucas P, Riesco JA, Rodríguez González-Moro JM. "Correct use of inhaled corticosteroids in chronic obstructtive pulmonary disease": a consensus document. Arch Bronconeumol 2015; 51(4):193-8. [CrossRef] [PubMed]

12. Magnussen $H$, Watz $H$, Kirsten A, Decramer M, Dahl R, Calverley PM, et al. Stepwise withdrawal of inhaled corticosteroids in COPD patients receiving dual bronchodilation: WISDOM study design and rationale. Resp Med 2014; 108(4):593-9. [CrossRef] [PubMed]

13. Bhalla S, Andurkar SV, Gulati A. Neurobiology of opioid withdrawal: Role of the endothelin system. Life Sci 2016; 15:34-42. [CrossRef] [PubMed]

14. Daitch D, Daitch J, Novinson D, Frey M, Mitnick C, Pergolizzi J Jr. Conversion from high-dose full-opioid agonists to sublingual buprenorphine reduces pain scores and improves quality of life for chronic pain patients. Pain Med 2014; 15(12):2087-94. [CrossRef] [PubMed]

15. Weber GM, Smerling AJ, Saroyan JM. Pentobarbital withdrawal and treatment in an infant in the pediatric cardiac intensive care unit. J Clin Anesth 2013; 25(1): 62-5. [CrossRef] [PubMed]

16. Cuadra R, White WB. Severe and refractory hypertension in a young woman. J Am Soc Hypertens 2016; 10(6):506-9. [CrossRef] [PubMed]

17. Koracevic G. Significance of "beta blocker rebound phenomenon" and new suggestions how to avoid it. In: Rivas-Echeverria C, Allegaert K, Wainstein DE, editors. Proceedings of the World Medical Conference; 2011 Sep 26-28; Prague, Czech Republic. p. 79-84.
18. Prins KW, Neill JM, Tyler JO, Eckman PM, Duval S. Effects of beta-blocker withdrawal in acute decompensated heart failure: A systematic review and metaanalysis. JACC-Heart Fail 2015; 3(8):647-53.

[CrossRef] [PubMed]

19. Schonberger RB, Feinleib J, Holt N, Dai F, Brandt C, Burg MM. Preoperative depression symptom severity and its impact on adherence to preoperative betablocker therapy. J Cardiothor Vasc An 2014; 28(6): 1467-73. [CrossRef] [PubMed]

20. Koracevic G. Acute right ventricular myocardial infarction: a very specific entity. Baylor University Medical Center Proceedings 2007; 20(2):177-8.

[CrossRef] [PubMed]

21. Koracevic GP, Dakic SS, Velickovic-Radovanovic R, Apostolović SR, Krstić NH, Tasić IS, et al. Amlodipine as an antiischemic drug is superior to long acting nitrates. Open Med-Warsaw 2015; 10(1):50-6. [CrossRef] [PubMed]

22. Imberti JF, Underwood K, Mazzanti A, Priori SG. Clinical challenges in catecholaminergic polymorphic ventricular tachycardia. Heart Lung Circ 2016; 25(8): 777-83. [CrossRef] [PubMed]

23. Koracevic G. 'Heparin rebound' means the opposite in cardiac surgery (bleeding) and in cardiology (thrombosis). Blood Coagul Fibrin 2010; 21(2):198-9.

[CrossRef] [PubMed]

24. Braillon A. Letter: interruption of beta-blockers in patients with cirrhosis - hasten slowly! Aliment Pharm Ther 2016; 43(11):1250-1. [CrossRef] [PubMed]

25. Koraćević G, Andrejević S, Sakač D, Stanojević Z, Stefanović S, Antović J, et al. Heparin rebound phenomenon in acute coronary syndromes: advantage of low molecular weight heparins. Facta Universitatis (Medicine and Biology) 2000; 7(1):62-9.

26. Vats A, Marbaniang MJ, Howell SJ. Perioperative management of the patient with cardiovascular disease undergoing non-cardiac surgery. Surgery (Oxford) 2016; 34(8):392-8. [CrossRef] 


\title{
FENOMEN NAGLE OBUSTAVE LEKA - VAŽAN I SVEPRISUTAN U FARMAKOTERAPIJI
}

\author{
Maja Koraćević ${ }^{1}$, Jelena Lalić1 ${ }^{1}$ Sonja Nedeljković ${ }^{2}$, Goran Koraćevićc,4 \\ ${ }^{1}$ Univerzitet u Nišu, Medicinski fakultet, Odsek za farmaciju, Niš, Srbija \\ ${ }^{2}$ Apoteka "Nevenpharm", Niš, Srbija \\ 3Univerzitet u Nišu, Medicinski fakultet, Niš, Srbija \\ ${ }^{4}$ Klinika za kardiovaskularne bolesti, Klinički centar Niš, Srbija \\ Kontakt: Maja Koraćević \\ 9. brigade 53/50, 18000 Niš, Srbija \\ E-mail: koracevic.maja@gmail.com
}

Efekat nagle obustave leka ("rebound efekat") predstavlja čestu karakteristiku brojnih klasa savremenih lekova i može dovesti do ozbiljnih, pa čak i fatalnih poremećaja. Na primer, produžena primena inhibitora protonske pumpe (PPI) dovodi do umerene hipergastrinemije kod $20-25 \%$ bolesnika. Ova hipergastrinemia će rezultirati znatnim porastom sekrecije želudačne kiseline kod 30-40\% bolesnika nakon naglog prekida uzimanja PPI, koji su među najčešće korišćenim lekovima u svetu.

Nagli prestanak hroničnog tretmana kortikosteroidom, beta blokatorom ili opijatom može takođe izazvati "rebound fenomen". Čak je i kod bolesnika sa srčanom insuficijencijom obustava beta blokatora na prijemu rezultirala značajnim porastom verovatnoće za intrahospitalnu smitnost.

Učestalost pojave "rebound fenomena" zavisi od brojnih činilaca, uključujući jačinu i trajanje dejstva određenog leka i koliko dugo je primenjivan; podložnost pojedinačnog bolesnika (u vezi komorbiditeta i ozbiljnosti osnovne bolesti) i povezanim okolnostima (npr, koterapija). Klinički značaj "rebound fenomena" varira od akademskog do smrtonosnog. Iako su retki, "rebound fenomeni" nekih klasa lekova postaju veoma važni ukoliko se lek koristi često i globalno.

Acta Medica Medianae 2018;57(4):148-152. opioid

Ključne reči: rebound, inhibitor protonske pumpe, kortikosteroid, beta blokator, 